\title{
Some Physical Properties of Paddy Seeds and Fertilizer
}

\author{
Kipoo Kiran Singh Mahilang ${ }^{1 *}$, Khilendra Sonboier ${ }^{2}$, Pankaj Minj ${ }^{2}$, \\ Yogesh Jaisawal $^{2}$, Navneet Khare ${ }^{3}$ and Tapti Taran Mahilang ${ }^{4}$ \\ ${ }^{1}$ Department of FMP, SVCAET\&RS, IGKV, Raipur, CG, India \\ ${ }^{2}$ Department of APFE, SHIATS, Allahabad, UP, India \\ ${ }^{3}$ Department of APFE, SVCAET\&RS, IGKV, Raipur, CG, India \\ ${ }^{4}$ Department of FPT, Bilaspur University, Bilaspur, CG, India \\ *Corresponding author
}

\begin{tabular}{|l|}
\hline Key w o r d s \\
Paddy, DAP, \\
Sphericity, Paddy \\
drum seeders, \\
Geometric mean \\
diameter
\end{tabular}

\section{A B S T R A C T}

Knowledge on physical properties of seeds is one of the most important parameter before designing of agricultural machines or any other equipment. The variety of paddy seeds taken for the study was Karma Mahsuri and shape was cylindrical while variety of fertilizer taken for study was DAP granules and shape was round. The research work was carried out in the laboratory at the Department of Farm Machinery and Power, SVCAET\&RS, IGKV, Raipur. The main aim of the study was to determine the physical properties of paddy seeds and fertilizer (DAP granules) which will be beneficial for designing of sowing related machines like Paddy drum seeders, seed drills and seed cum fertilizer drills. Test Parameters taken for the study were geometric dimensions of Paddy seeds and DAP granules i.e. Average length (L), width (W) and thickness (T), Geometric mean diameter (Dp), Sphericity $(\phi)$, Mass and Bulk density. The results showed that the average length, width and thickness of paddy seeds varied from 8.61 to $11.29 \mathrm{~mm}, 2.55$ to $3.03 \mathrm{~mm}$ and 2.08 to $2.50 \mathrm{~mm}$ respectively while DAP granules varied from 5.43 to 6.39 $\mathrm{mm}, 4.74$ to $5.29 \mathrm{~mm}$ and 3.10 to $3.30 \mathrm{~mm}$ respectively. The bulk density by Mohsenin method for paddy seed was observed as $603 \mathrm{~kg} / \mathrm{m}^{3}$ whereas the average weight of 1000 paddy seeds sample was measured as $35 \mathrm{gm}$. The Geometric mean diameter (Dp) by Mohsenin method and Sphericity by Sahay and Singh method for paddy was $3.90 \mathrm{~mm}$ and 0.41 while for DAP granules it was $4.57 \mathrm{~mm}$ and 0.76 respectively.

\section{Introduction}

Agriculture is the backbone of most economies in India and quality seed is the fuel for agricultural development. Rice (Oryzae sativa) belongs to the grass family Oryzeae, and is one of the leading food crops in the world. As, it is an important source of energy it is considered to be the second most highly- consumed food source on the planet earth (Anonymous, 2011).

India is the second largest producer after china with the production of 264.77 million tonnes with the productivity of $2415.8 \mathrm{~kg} / \mathrm{ha}$ in 2013 14. (Source: Directorate of Economics and Statistics, Department of Agriculture and Cooperation). Rice being the main source of 
livelihood for more than 120-150 million rural household is the backbone of the India Agriculture. It occupies about 23.3 per cent of the food grain production and 55 per cent of cereal production. The rice plays a vital role in the national food security (Anonymous, 2013).

Chhattisgarh popularly known as "Rice bowl of India" occupies an area of around 47.85 lakh hectares with the production of 6717 and 759.3 metric tones in kharif and rabi season with the productivity of $1983 \mathrm{~kg}$ per hectare of rice during the year 2013-14. (Source: Directorate of Economics and Statistics, Department of Agriculture, Chhattisgarh) (FAOSTATS, 2001).

The first experiments with 'fertilizer' started in the 17th century. The first phosphate fertilizers were ground bones treated with sulphuric acid. The first superphosphate production was started in 1842. Ammonium phosphate fertilizers first became available in the 1960s, and DAP rapidly became the most popular in this class of products.

Di-Ammonium Phosphate (DAP) is the world's most widely used Phosphorus fertilizer. It is made from two common constituents in the fertilizer industry Nitrogen $(\mathrm{N})$ and Phosphorus $(\mathrm{P})$.

It is the most popular phosphatic fertiliser because of its high analysis and good physical properties. The composition of DAP is $\mathrm{N}-18 \%$ and $\mathrm{P}_{2} \mathrm{O}_{5}-46 \%$ [FAOSTATS, 2010].

In, Chhattisgarh state, there are many varieties of paddy seeds which are developed in Indira Gandhi Agricultural University, Raipur and some of common varieties are like Mahamaya, Poornima, Danteshwari, Bambleshwari and Karma Mahsuri among which we have taken Karma Mahsuri seeds for study because it can be grown in all regions of Chhattisgarh state.
Similarly, DAP are most common fertilizer used in rice cultivation. It is relatively high in nutrient content and its excellent physical properties make it a popular choice in farming and other industries. So, keeping all the above facts and points an attempt have been made to study on some of the physical properties of paddy seeds and fertilizer so, that it will be somehow useful for manufacturers, researchers while designing of sowing related machines such as paddy drum seeders (Mahilang, 2015).

\section{Materials and Methods}

\section{Geometric dimensions of paddy seeds and fertilizer (DAP granules)}

Geometric dimensions of paddy seeds and DAP granules are determined by length, width and thickness.10 randomly selected paddy seeds and fertilizer (DAP granules) were measured by using the measuring scale and digital Vernier caliper.

\section{Average length (L), width (W) and thickness $(\mathbf{T})$}

Average length (L), width (W) and thickness (T) is calculated as followed (Mohsenin, 1986).

$$
\begin{aligned}
& \mathbf{L}=\frac{\sum_{i=1}^{n} \mathbf{L}}{n} \ldots(2.1) \\
& \mathbf{W}=\frac{\sum_{i=1}^{n} \mathbf{W}}{n} \ldots(2.2) \\
& \mathbf{T}=\frac{\sum_{i=1}^{n} \mathbf{T}}{n} \ldots(2.3)
\end{aligned}
$$

Where,

$\mathrm{L}=$ largest intercept (length), mm;

$\mathrm{W}=$ width, $\mathrm{mm}$; and

$\mathrm{T}=$ Thickness, $\mathrm{mm}$. 


\section{Geometric mean diameter (Dp)}

The geometric mean diameter (Dp) was calculated by using the following relationship (Mohsenin, 1986).

$\mathrm{D}_{\mathrm{P}}=(\boldsymbol{L W T})^{\frac{1}{3}} \ldots(\mathbf{2 . 4})$

Where,

$\mathrm{L}=$ largest intercept (length), $\mathrm{mm}$;

$\mathrm{W}=$ width, $\mathrm{mm}$; and

$\mathrm{T}=$ Thickness, $\mathrm{mm}$.

\section{Sphericity $(\phi)$}

Sphericity defines the ratio of the diameter of a sphere of the same volume as that of the particle and the diameter of the smallest circumscribing sphere or generally the largest diameter of the particle (Sahay and Singh, 1994). This parameter shows the shape character of paddy seeds relative to the sphere having the same volume.

Sphericity

$=\sqrt{\frac{\text { Volume of particles }}{\text { Volume of circumdsribed Sphere }}}$

$=\frac{(\mathrm{LWT})}{\mathrm{L}}^{1 / 3}$

Where,

$\mathrm{L}=$ largest intercept (length), $\mathrm{mm}$;

$\mathrm{W}=$ width, $\mathrm{mm}$; and

$\mathrm{T}=$ Thickness, $\mathrm{mm}$.

Mass of paddy seeds and fertilizer (DAP granules)

To Obtained the mass, 1000 randomly selected paddy seeds and fertilizer (DAP granules) were counted and weighed by using electronic balance with a least count up to $0.001 \mathrm{~g}$. The average weight of 1 seeds was. $037 \mathrm{~g}$ whereas the average weight of fertilizer (DAP granules) was $0.035 \mathrm{~g}$.

\section{Bulk density of paddy seeds}

Bulk density of paddy seeds was calculated by placing the sample of paddy seeds in a cylinder which has $7 \mathrm{~cm}$ of diameter and 9.6 $\mathrm{cm}$ of length. The sample placed in the cylinder is then weighed by using electronic balance with least count of $1 \mathrm{~g}$. Bulk density was calculated by using the relationship (Mohsenin, 1986).

$\mathbf{b}_{\mathrm{d}}=\frac{\mathbf{W}_{\mathrm{t}}}{\mathrm{L} \times\left(\frac{\pi \mathrm{d}^{2}}{4}\right)} \ldots(2.6)$

Where,

$b_{d}=$ Bulk density, $\mathrm{kg} / \mathrm{m}^{3}$;

$\mathrm{W}_{\mathrm{t}}=$ Weight of sample, $\mathrm{kg}$;

$\mathrm{L}=$ Length of cylinder, $\mathrm{m}$; and

$\mathrm{d}=$ Diameter of cylinder.

\section{Results and Discussion}

Physical characteristics of paddy seeds and fertilizer (DAP Granules)

\section{Size and unit mass of paddy seeds}

The variety of paddy seeds taken for the study was Karma Mahsuri and shape was cylindrical. Table 1 shows the size and unit mass distribution of paddy seed.

The length was found to be in range of 8.61 to $11.29 \mathrm{~mm}$ with the average length of 9.50 $\mathrm{mm}$. The SD and coefficient of variance was calculated to be $0.729 \mathrm{~cm}$ and 7.673 per cent respectively. Similarly width varies from 2.55 to $3.03 \mathrm{~mm}$ with average width of $2.82 \mathrm{~mm}$. The SD and coefficient of variance was calculated to be $0.143 \mathrm{~cm}$ and 5.070 per cent respectively. The thickness varies between 2.08 to $2.50 \mathrm{~mm}$ with average thickness of 
$2.22 \mathrm{~mm}$. The SD and coefficient of variance was calculated to be $0.133 \mathrm{~cm}$ and 5.990 per cent respectively.

The geometric mean diameter and sphericity of paddy seeds were found to be 3.90 and 0.41 on average of 10 paddy seeds. The SD of geometric mean diameter and sphericity was found to be $0.029 \mathrm{~cm}$ and 0.004 percent respectively. The coefficient of Variance for geometric mean diameter and sphericity was observed to be 0.743 and 0.975 percent respectively.

\section{Size and unit mass of fertilizer (DAP granules)}

The fertilizer taken for this study was DAP granules because it is commonly used by the farmers at the time of line sowing. The shape of DAP was round. Table 2 shows the size and unit mass distribution of fertilizer.

The length was found to be in range of 5.43 to $6.39 \mathrm{~mm}$ with the average length of $5.99 \mathrm{~mm}$.

The SD and coefficient of variance was calculated to be $0.338 \mathrm{~cm}$ and 5.642 per cent respectively. Similarly width varies from 4.74 to $5.29 \mathrm{~mm}$ with average width of $5.03 \mathrm{~mm}$. The SD and coefficient of variance was calculated to be $0.212 \mathrm{~cm}$ and 4.212 per cent respectively.

The thickness varies between 3.10 to $3.30 \mathrm{~mm}$ with average thickness of $3.19 \mathrm{~mm}$. The SD and coefficient of variance was calculated to be $0.075 \mathrm{~cm}$ and 2.35 per cent respectively.

Fig.1 Measurement of dimensions of paddy seeds and DAP granules using digital vernier caliper
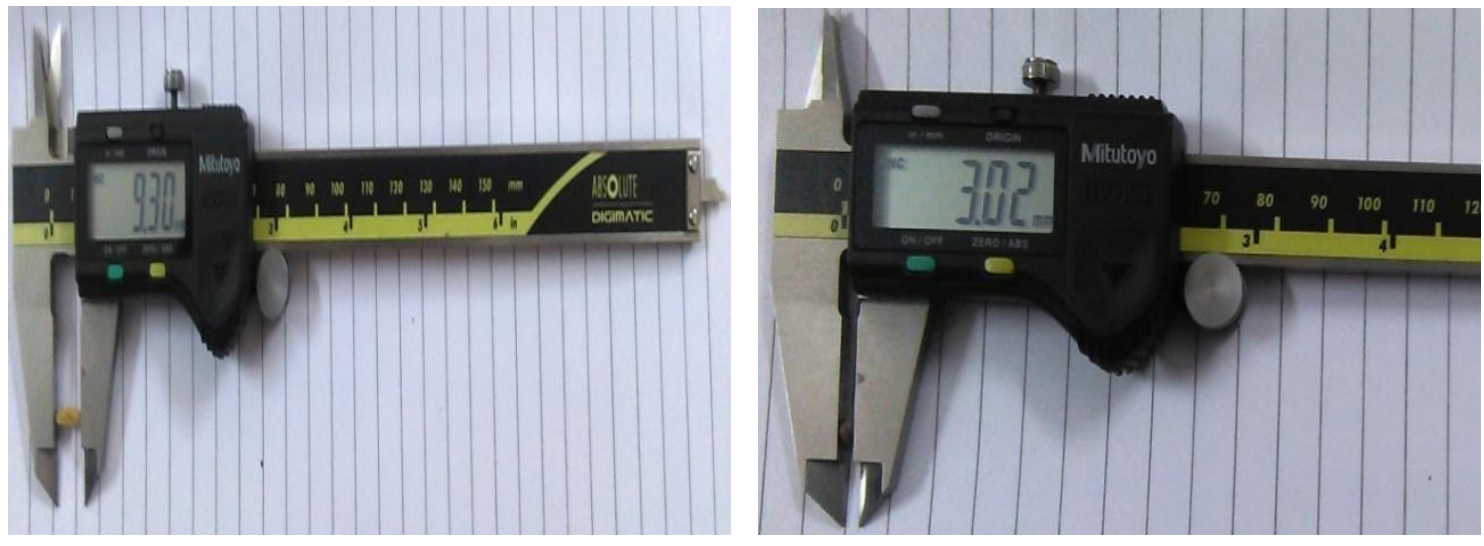

Fig.2 1000 samples of fertilizer (DAP granules) and paddy seeds
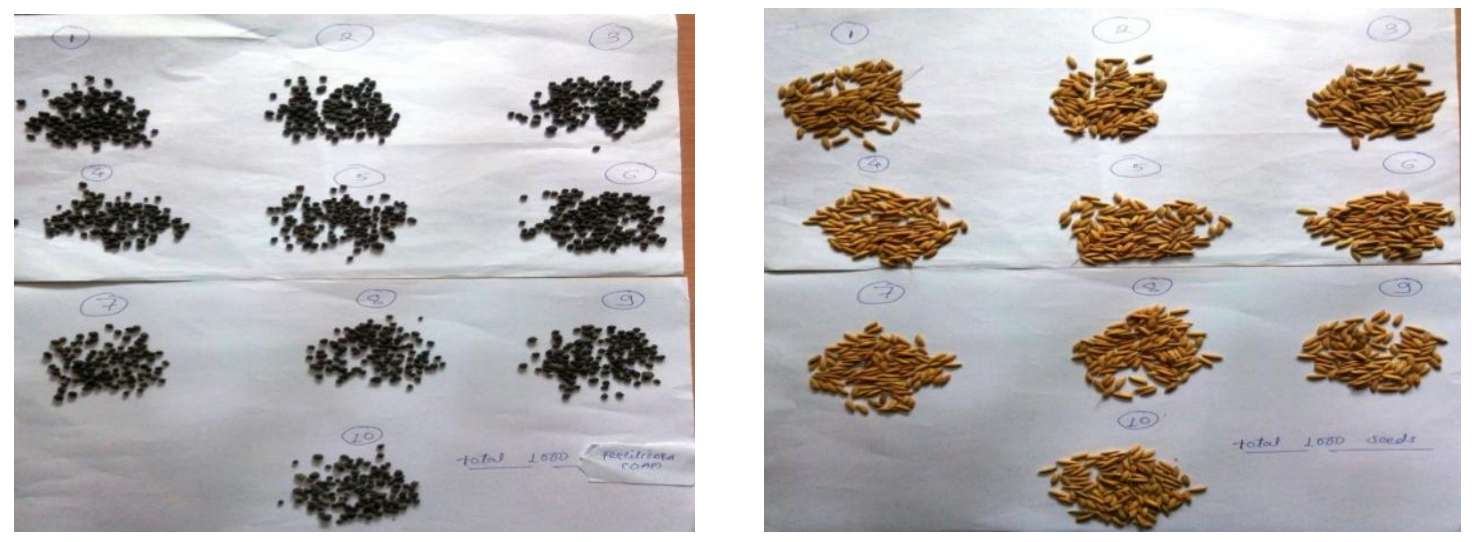
Fig.3 Measurement of mass of 1000 samples of paddy seeds and fertilizer (DAP) by electronics balance
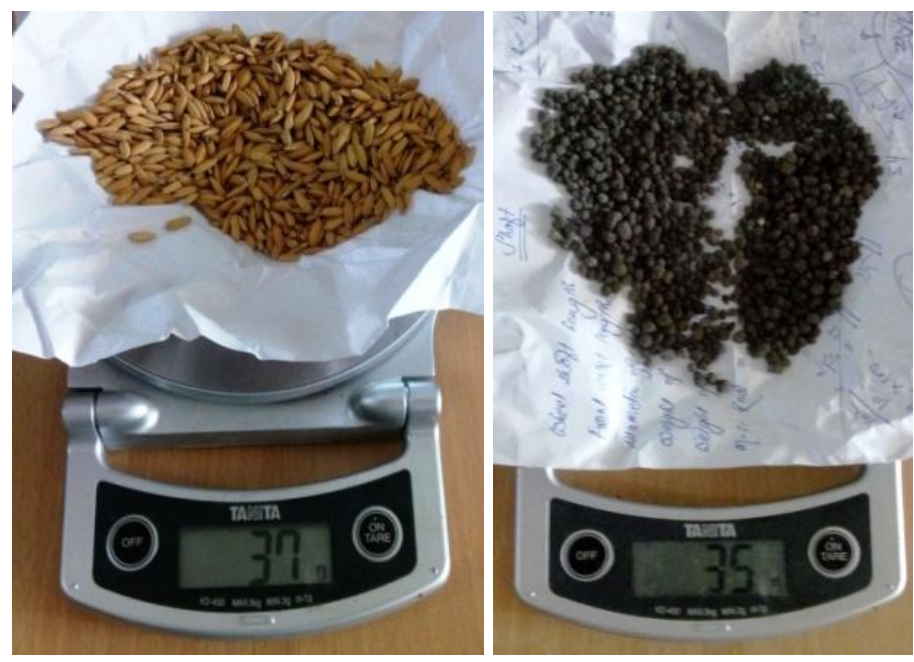

Table.1 Geometric properties of selected paddy seeds

\begin{tabular}{|c|c|c|c|c|c|c|}
\hline S. No. & $\begin{array}{l}\text { Length, } \\
\text { mm }\end{array}$ & $\begin{array}{l}\text { Width, } \\
\text { mm }\end{array}$ & $\begin{array}{c}\text { Thickness, } \\
\text { mm }\end{array}$ & $\begin{array}{c}\text { Geometric } \\
\text { mean dia, } \\
\text { mm }\end{array}$ & Sphericity & $\begin{array}{l}\text { Weight } \\
\text { of } 1000 \\
\text { seeds, g }\end{array}$ \\
\hline 1. & 9.30 & 2.92 & 2.22 & 3.92 & 0.42 & \multirow[t]{14}{*}{37} \\
\hline 2. & 11.29 & 2.85 & 2.36 & 4.24 & 0.37 & \\
\hline 3. & 9.57 & 3.03 & 2.30 & 4.05 & 0.42 & \\
\hline 4. & 9.25 & 2.79 & 2.22 & 3.85 & 0.41 & \\
\hline 5. & 8.61 & 2.83 & 2.11 & 3.71 & 0.43 & \\
\hline 6. & 9.69 & 2.75 & 2.08 & 3.81 & 0.39 & \\
\hline 7. & 8.72 & 2.80 & 2.10 & 3.72 & 0.42 & \\
\hline 8. & 9.67 & 2.73 & 2.12 & 3.82 & 0.39 & \\
\hline 9. & 9.53 & 2.55 & 2.25 & 3.79 & 0.39 & \\
\hline 10. & 9.37 & 3.03 & 2.50 & 4.14 & 0.44 & \\
\hline Avg & 9.50 & 2.82 & 2.22 & 3.90 & 0.41 & \\
\hline Range & 8.61 - 11.29 & $2.55-3.03$ & $2.08-2.50$ & $3.71-4.24$ & $0.37-0.44$ & \\
\hline SD & 0.729 & 0.143 & 0.133 & 0.029 & 0.004 & \\
\hline $\mathrm{CV}$ & 7.673 & 5.070 & 5.990 & 0.743 & 0.975 & \\
\hline
\end{tabular}


Table.2 Geometric properties of selected fertilizer (DAP granules)

\begin{tabular}{|c|c|c|c|c|c|c|}
\hline S. No. & $\begin{array}{c}\text { Length, } \\
\text { Mm }\end{array}$ & $\begin{array}{c}\text { Width, } \\
\text { mm }\end{array}$ & $\begin{array}{c}\text { Thickness, } \\
\text { mm }\end{array}$ & $\begin{array}{c}\text { Geometric } \\
\text { mean diameter, } \\
\text { mm }\end{array}$ & Sphericity & $\begin{array}{c}\text { Weight of } 1000 \\
\text { DAP granules, } \\
\text { gm }\end{array}$ \\
\hline $\mathbf{1 .}$ & 6.13 & 5.29 & 3.12 & 4.65 & 0.75 & $\mathbf{3 5}$ \\
\hline $\mathbf{2 .}$ & 6.22 & 5.21 & 3.14 & 4.66 & 0.74 & \\
\hline $\mathbf{3 .}$ & 5.43 & 5.27 & 3.22 & 4.51 & 0.83 & \\
\hline $\mathbf{4 .}$ & 6.08 & 5.03 & 3.30 & 4.65 & 0.76 \\
\hline $\mathbf{5 .}$ & 6.23 & 4.85 & 3.15 & 4.56 & 0.73 \\
\hline $\mathbf{6 .}$ & 5.45 & 4.74 & 3.10 & 4.31 & 0.79 \\
\hline $\mathbf{7 .}$ & 6.11 & 4.90 & 3.17 & 4.56 & 0.74 \\
\hline $\mathbf{8 .}$ & 6.39 & 5.19 & 3.28 & 4.77 & 0.74 \\
\hline $\mathbf{9 .}$ & 5.71 & 5.10 & 3.14 & 4.50 & 0.78 \\
\hline $\mathbf{1 0}$ & 6.17 & 4.74 & 3.29 & 4.58 & 0.74 \\
\hline Avg & $\mathbf{5 . 9 9}$ & $\mathbf{5 . 0 3}$ & $\mathbf{3 . 1 9}$ & $\mathbf{4 . 5 7}$ & $\mathbf{0 . 7 6}$ & \\
\hline Range & $\mathbf{5 . 4 3 - 6 . 3 9}$ & $\mathbf{4 . 7 4 - 5 . 2 9}$ & $\mathbf{3 . 1 0}-\mathbf{3 . 3 0}$ & $\mathbf{4 . 3 1 - 4 . 7 7}$ & $\mathbf{0 . 7 3 - 0 . 8 4}$ \\
\hline SD & 0.338 & 0.212 & 0.075 & 0.0137 & 0.0008 \\
\hline CV & 5.642 & 4.212 & 2.35 & 0.299 & 0.105 \\
\end{tabular}

Table.3 Determination of bulk density of paddy seeds

\begin{tabular}{|c|c|c|c|c|}
\hline Sample No & $\begin{array}{c}\text { Sample weight, } \\
(\mathrm{g})\end{array}$ & $\begin{array}{c}\text { Volume of } \\
\text { cylinder, }(\mathbf{c m} 3)\end{array}$ & $\begin{array}{c}\text { Bulk density, } \\
(\mathrm{kg} / \mathrm{m3})\end{array}$ & $\begin{array}{c}\text { Moisture } \\
\text { Content }\end{array}$ \\
\hline Sample I & 220.00 & 369.26 & 595.78 & 5.05 \\
\hline Sample II & 218.00 & 369.26 & 590.36 & 5.20 \\
\hline Sample III & 230.00 & 369.26 & 622.86 & 5.34 \\
\hline Mean & $\mathbf{2 2 2 . 6 7}$ & $\mathbf{3 6 9 . 2 6}$ & $\mathbf{6 0 3 . 0 0}$ & $\mathbf{5 . 1 9}$ \\
\hline Range & $\mathbf{2 1 8 - 2 3 0}$ & & $\mathbf{5 9 0 . 3 6 - 5 9 5 . 7 8}$ & $\mathbf{5 . 0 5}-\mathbf{5 . 3 4}$ \\
\hline
\end{tabular}

The geometric mean diameter and sphericity of fertilizer were found to be 4.57 and 0.76 $\mathrm{cm}$ on average of 10 DAP granules. The SD of geometric mean diameter and sphericity was found to be 0.0137 and 0.0008 respectively. The coefficient of variation for geometric mean diameter and sphericity was observed to be 0.299 and 0.105 percent respectively.

\section{Bulk density of paddy seeds}

Bulk density of paddy seeds is an important parameter for designing of capacity of drums.
Three replicated trials were conducted using a cylindrical beaker having diameter $7 \mathrm{~cm}$ and length of $9.6 \mathrm{~cm}$.

Average weight of sample was found to be $222.67 \mathrm{~g}$ and the bulk density obtained was $603 \mathrm{~kg} / \mathrm{m}^{3}$. The range of bulk density varied from 590.36 to $595.78 \mathrm{~kg} / \mathrm{m}^{3}$. Table 3 shows bulk density of paddy seeds (Fig. 1-3).

The following conclusions are drawn from this investigation on physical properties of paddy seed and fertilizer. The variety of the paddy seed taken for study was Karma 
Mahsuri. The average length, width and thickness of paddy seed was $9.50 \mathrm{~mm}, 2.82$ $\mathrm{mm}$ and $2.22 \mathrm{~mm}$ respectively and average weight of 1000 paddy seeds was $37 \mathrm{gm}$. The variety of the fertilizers taken for study was DAP. The average length, width and thickness of paddy seed was $5.99 \mathrm{~mm}, 5.03$ $\mathrm{mm}$ and $3.19 \mathrm{~mm}$ respectively and average weight of 1000 paddy seeds was 35 gm. From engineering, point of view this all information are useful for designing of sowing related machines like seed cum fertilizer applicator, paddy drum seeders using Karma Mahsuri as paddy seed and DAP granules as fertilizer.

\section{References}

Anonymous, 2011. Annual Report of AICRP on Utilization of Animal Energy. Faculty of Agricultural Engineering, IGKV Raipur (C.G).

Anonymous, 2013. Annual Report of AICRP on Utilization of Animal Energy. Faculty of Agricultural Engineering, IGKV Raipur (C.G).

FAOSTATS, 2001. Statistical database of the food and agricultural organization of the United Nations. Cited in: Xiang et al., 2006. Mapping paddy agriculture in south and south East Asia using multi temporal MODIS images. Remote Sensing of Envt. 100: 95-113.
FAOSTATS, 2010. Statistical database of the food and agricultural organization of the United Nations.

Khan, A. U. 1975. International Rice Research Institute, Annual Report, Los Banos, Philippines.

Krishnaiah, K. 1999. Row seeder for sowing rice in puddle soil. ICAR News, ICAR, Krishi Bhavan, New Delhi, India, Vol. (5), No.1, pp. 12.

Mahilang, K.K.S. Design and Development of seed cum fertilizer applicator for direct seeded rice. M. Tech. Thesis, IGKV, Raipur; 2015.

Mohsenin, N. N. 1986. Physical Properties of Plant and Animal Materials: structure, physical characteristics and mechanical properties, $2^{\text {nd }}$ rev. and updated ed., New York: Gordon and Breach Science Publishers.

Sahay, K. M. and Singh, K. K. 2010. Unit operations in agricultural processing. New Delhi: Vikas Publishing House Pvt. Ltd.

Venkateswarlu B. 1980. All India Co. ordinate Rice improvement Project, Rajendranagar, Hyderabad. Indian Farming, February: 3-5.

Verma, A.K. 1999. Annual Report - Results of Kharif. Faculty of Agricultural Engineering, IGKV, Raipur (CG).

\section{How to cite this article:}

Kipoo Kiran Singh Mahilang, Khilendra Sonboier, Pankaj Minj, Yogesh Jaisawal, Navneet Khare and Tapti Taran Mahilang. 2018. Some Physical Properties of Paddy Seeds and Fertilizer. Int.J.Curr.Microbiol.App.Sci. 7(02): 235-241. doi: https://doi.org/10.20546/ijcmas.2018.702.030 